\title{
Silicon uptake and distribution in Agropyron smithii as related to grazing history and defoliation
}

\author{
M.S. CID, J.K. DETLING, A.D. WHICKER, AND M.A. BRIZUELA
}

\section{Abstract}

A controlled environment experiment was performed on plants from 2 A gropyron smithii $R y d b$. (western wheatgrass) populations to determine how defoliation at 6-week intervals and grazing history affected total silicon accumulation in shoots, and how $\mathrm{Sj}$ was distributed within the plant. Plants were collected from a heavily grazed, 40-year-old prairie dog colony and an ungrazed, 40-yearold exclosure at Wind Cave National Park, South Dakota. After 18 weeks, the total amount of Si accumulated in shoots was similar in plants from both populations, regardless of whether or not the plants were clipped. However, the Si concentration in shoots was greater in nondefoliated than defoliated plants of both populations because of Si dilution resulting from greater shoot production in defoliated plants. In both populations, roots and leaf blades had the highest Si concentrations, rhizomes had the lowest concentrations, and sheaths, crowns, and belowground stems had intermediate concentrations.

Key Words: biomass production, clipping, growth chamber, prairie dog colonies, western wheatgrass

Because of its potential effects on forage quality, diet preference, and grass-grazer co-evolution (Minson 1971, Stebbins 1981, Van Soest 1982), silica in grasses has received considerable attention by ecologists and range scientists (Shewmaker et al. 1989). In a controlled environment experiment with 3 perennial African grass species, McNaughton and Tarrants (1983) and McNaughton et al. (1985) reported that (1) leaf silicification was enhanced by defoliation, (2) plants from populations collected from heavily grazed areas had higher leaf silica concentrations than those collected from less intensively grazed areas, and (3) silica concentration of plant parts generally decreased from roots to blades. McNaughton et al. (1985) invoked an evolutionary hypothesis involving differences in tissue priority and history of herbivore exposure to explain their findings. Specifically, they viewed silica as an antiherbivore defense chemical which was quantitatively inducible in grass shoots, and whose exceptionally high concentrations in roots (the least expendable organ) was a consequence of heavy selection pressure by fossorial herbivores.

We conducted a series of integrated field and laboratory studies to evaluate these ideas of McNaughton and colleagues for some North American grasses with different grazing histories. In the field at Wind Cave National Park, South Dakota, Si concentrations in tillers without visible signs of current-season grazing were consistently and significantly higher in plants of Agropyron smithii Rydb. and Schizachryium scoparium (Michx.) Nash on heavily grazed prairie dog (Cynomys ludovicianus Ord) colonies than on

\footnotetext{
Cid and Brizuela are professors, Facultad de Ciencias Agrarias, Universidad Nacional de Mar del Plata (7620) Balcarce, Argentina; Detling is senior research scientist, Natural Resource Ecology Laboratory, and professor, Department of Range Science, Colorado State University, Fort Collins 80523; Whicker is research associate, Natural Resource Ecology Laboratory. At the time of this research, Cid and Brizuela were visiting scientists, Natural Resource Ecology Laboratory, and graduate students, Department of Range Science.

We are grateful for the assistance of Mr. Rich Klukas and the staff of Wind Cave National Park for their support and cooperation. This work was supported by funds from Consejo Nacional de Investigaciones Cientificas y Tecnicas (Argentina) and National Science Foundation (USA) Grants DEB 8022380 and BSR 8406660.

Manuscript accepted 29 November 1989.
}

adjacent, lightly grazed, uncolonized areas (Brizuela et al. 1986). After more than 2 years following transplantation of $A$. smithii to a greenhouse and controlled environment chambers, these population differences in shoot Si concentration were maintained (Cid et al. 1989). However, in both our field (in a separate study conducted within a grazing exclosure) and growth chamber experiments, defoliated plants had lower leaf Si concentrations than nondefoliated plants, suggesting that leaf silicification is not inducible in these 2 North American species.

The objective of the controlled environment experiments described in this paper was to address 2 remaining questions concerning $S i$ in A. smithii: (1) how is total aboveground accumulation of $\mathrm{Si}$ affected by defoliation and recent $(\sim \mathbf{4 0}$ years) grazing history, and (2) how does the vertical distribution of $\mathrm{Si}$ in 2 populations of this species compare with that of the African grasses studied by McNaughton and colleagues?

\section{Materials and Methods}

Plants from the ungrazed population of $A$. smithii were collected from within a 40-year-old exclosure surrounding Wind Cave National Park headquarters, and those from the heavily grazed population were collected from an area of Bison Flats prairie dog colony which had been colonized about 40 years (Cid et al. 1989). Plants were collected and propagated in a greenhouse for 2 years before the experiment (Cid et al. 1989). Previous studies have established that morphological differences, including a shorter, more prostrate growth habit and higher leaf blade:sheath and blade:culm ratios, occur in $A$. smithii plants from prairie dog colonies relative to those from uncolonized areas, and that these differences are likely the result of genetic differentiation caused by heavy selection pressure from grazers (Detling and Painter 1983, Detling et al. 1986, Polley and Detling 1988, Cid et al. 1989, Painter 1987). In addition, these and other studies (Jaramillo and Detling 1988, Painter et al. 1989) have shown that plants from prairie dog colony and uncolonized populations often respond differently to defoliation.

A total of 28 A. smithii plants, 14 from each population, were used in this study. Potted plants were grown in calcined clay (Van Bavel et al. 1978) in a Conviron E-15 growth chamber with 14-h photoperiods, light/dark temperatures of $20 / 14^{\circ} \mathrm{C}$, and a quantum flux density of $700 \mu \mathrm{E} \bullet \mathrm{m}^{-2} \bullet \mathrm{s}^{-1}$. Plants were watered every 2 days with deionized water and, on alternate days, with $100 \mathrm{ml}$ of full-strength Hoagland's solution No. 1 to which $100 \mathrm{ppm}$ of soluble silica was added as $\mathrm{NaSiO}_{3} \bullet 9 \mathrm{H}_{2} \mathrm{O}$ (McNaughton and Tarrants 1983, McNaughton et al. 1985).

After 9 weeks under these conditions, plants from each population were randomly assigned to nondefoliated or defoliated treatments. Clipping heights were one-half the mean height to the ligule of the uppermost leaf at Week $0: 3.5 \mathrm{~cm}$ for the shorter plants from the prairie dog colony and $5.5 \mathrm{~cm}$ for the taller exclosure plants. Plants in the defoliated treatment were clipped 4 times, at 6-week intervals, at these heights. On the final sampling date (Week 18), plants which had not been defoliated were also clipped at these heights. Also on this date, belowground and remaining above- 

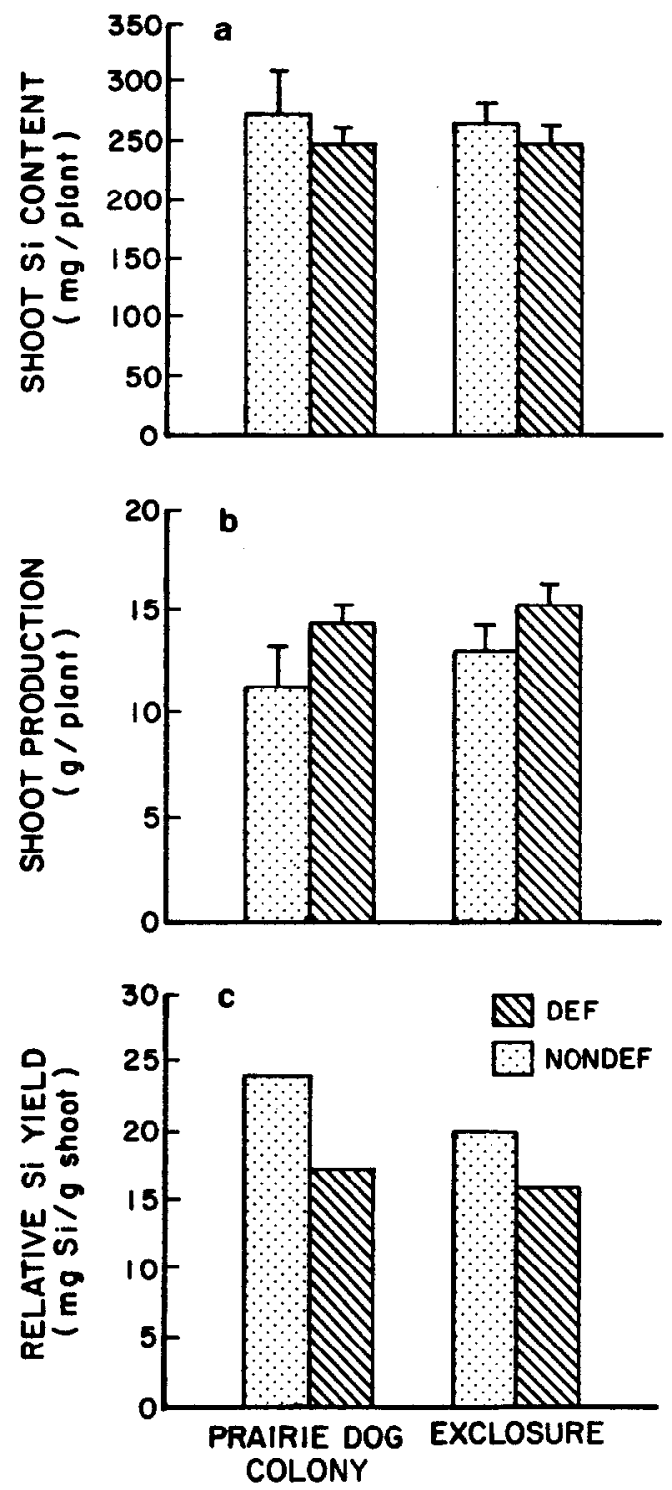

Fig. 1. Effects of defoliation and population origin (heavily grazed prairie dog colony or exclosure) on: (a) cumulative shoot silicon content above clipping height, (b) cumulative shoot biomass production, and (c) relative sillicon yield (cumulative shoot Si content/shoot biomass production) of Agropyron smithit. Vertical bars in (a) and (b) represent one standard error.

ground biomass from the undefoliated plants of each population were collected for analysis of vertical distribution patterns of Si. All harvested material was separated into component parts, dried at $60^{\circ} \mathrm{C}$ to a constant weight, weighed, and analyzed for $\mathrm{Si}$ colorimetrically (Fox et al. 1969).

A two-way ANOVA (defoliation $\times$ plant part) and, following a significant F-test in the ANOVA, Tukey's HSD was used to define homogeneous subgroups. In all analyses, differences were accepted as statistically significant at $\boldsymbol{p} \leq \mathbf{0 . 0 5}$.

\section{Results}

The total amount of Si accumulated in shoots above the clipping height did not differ significantly between populations or defoliation treatments, and there was not a significant population $\times$ defoliation interaction (Fig. la). Although there also was not a significant difference in cumulative shoot biomass production between populations, defoliation at 6-week intervals did significantly increase production above the clipping height (Fig. lb). Again, there was no significant interaction between populations and defoliation treatment, indicating that the 2 populations responded similarly to defoliation. Thus, across populations, aboveground production of defoliated plants $(14.9 \mathrm{~g} / \mathrm{plant})$ averaged $22 \%$ greater than that of nondefoliated plants $(12.2 \mathrm{~g} /$ plant $)$. Relative Si yield (cumulative shoot Si content per unit of shoot biomass prduction) calculated from these measurements (Fig. Ic) was higher on nondefoliated plants $(22.1 \mathrm{mg} \mathrm{Si} / \mathrm{g}$ plant) than in defoliated plants ( $16.7 \mathrm{mg} \mathrm{Si} / \mathrm{g}$ plant).

Vertical patterns of Si distribution within entire plants of the undefoliated treatment did not differ significantly between populations, nor was there a plant part $X$ population interaction. However, $\mathrm{Si}$ concentrations did vary significantly among plant parts (Fig. 2). The highest Si concentrations were in the roots and leaf

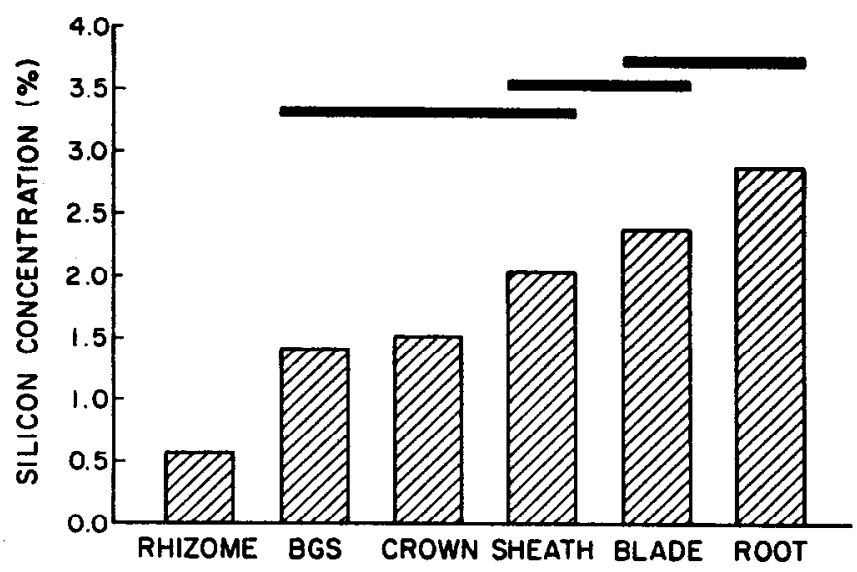

Fit. 2. Vertical distribution patterns of silicon in component parts (BGS=belowground stems) of nondefoliated Agropyron swithti plants averaged across populations collected from a prairie dog colony and a graxing exclosure. Si concentrations of components under the same horizontal bar are not signineantly different $(p \leq 0.05)$.

blades, which did not differ significantly from each other. Rhizomes had the lowest Si concentrations, while sheaths, crowns and belowground portions of stems comprised an intermediate group.

\section{Discussion}

Although defoliation of $A$. smithii at the level and frequency imposed in this study results in lowered leaf Si concentrations (Cid et al. 1989), this is probably not because of decreased Si uptake and translocation to shoots. Rather, in both populations, similar quantities of Si were found in the shoot tissues produced above the clipping heights of both defoliated and nondefoliated plants (Fig. 1a). Thus, the lower shoot Si concentrations in defoliated plants apparently resulted from this quantity of silicon being distributed throughout more biomass (Fig. 1b). The greater shoot biomass production of defoliated plants was unexpected since other field and growth studies on $A$. smithii (Painter and Detling 1981, Hart and Balla 1982, Polley and Detling 1988) and numerous other North American grasses (Detling 1988) have usually reported either a production decline or no effect of defoliation on production. Defoliation may have enhanced aboveground production in this study because the clipping intervals and total duration of the experiment were longer than those used in many similar studies, thereby providing more time for recovery and overcompensation (sensu Belsky 1986) to occur (Hilbert et al. 1981).

The decrease in relative Si yield (accumulation per unit of shoot production) following repeated defoliation is also of interest. Other revorts have indicated that. for essential hut frementlv 
limiting nutrients such as $\mathbf{N}$ and $P$, either total nutrient uptake or nutrient yield per unit of biomass produced increase following defoliation (Ruess et al. 1983, McNaughton and Chapin 1985, Jaramillo and Detling 1988). The absence of either response for $\mathrm{Si}$ in $A$. smithii may indicate that it is nonlimiting and less preferentially allocated to shoots following defoliation than are essential nutrients.

The vertical distribution patterns of $\mathrm{Si}$ in these populations of $A$. smithii differed markedly from those of the perennial African grasses studied by McNaughton et al. (1985). While they reported a progressive four-fold decrease in Si concentration from roots to leaf blades in samples composited from several species, the roots and blades of $A$. smithii had similar Si concentrations (Fig. 2). Furthermore, within the shoot system of $A$. smithii, Si concentrations increased with increasing distance from the roots. Although some species apparently exhibit active uptake of $\mathrm{Si}$ (Marschner 1986), patterns similar to those in $A$. smithii are common in graminaceous crop species (Jones et al. 1963, Tanaka and Park 1966, Lanning et al. 1980). Such patterns have been attributed to the nonselective uptake of $\mathrm{Si}$ followed by its passive transport in the transpiration stream and subsequent deposition in leaf blades following evaporation of water (Handreck and Jones 1968, Marschner 1986). This interpretation differs markedly from the plant-herbivore coevolutionary hypothesis advanced by McNaughton et al. (1985).

Although previous studies (Brizuela et al. 1986, Cid et al. 1989) have indicated that shoots of $A$. smithii plants from heavily grazed prairie dog colony populations have higher Si concentrations than do those from uncolonized areas, the differences were relatively small ( 2.2 vs. $1.9 \%$ ) in a controlled environment experiment (Cid et al. 1989). In addition, prairie dog colonies are preferentially selected for grazing by bison over adjacent uncolonized areas (Coppock et al. 1983, Krueger 1986). These observations, coupled with reports that diet preferences of sheep (Minson 1971, Shewmaker et al. 1989) and cattle (Truscott and Currie 1989) are typically not related to forage Si concentration, suggest that relatively small population differences in leaf Si concentrations (Brizuela et al. 1986, Cid et al. 1989) may not be a major factor in grazing site selection by large ungulates.

\section{Literature Cited}

Belsky, A.J. 1986. Does herbivory benefit plants? A review of the evidence. Amer. Natur. 127:870-892.

Brizuela, M.A., J.K. Detling, and M.S. Cid. 1986. Silicon concentration of grasses growing in sites with different grazing histories. Ecology 67:1098-1101.

Cid, M.S., J.K. Detling, M.A. Brizuela, and A.D. Whicker. 1989. Patterns in grass silicification: response to grazing history and defoliation. Oecologia 80:268-271.

Coppock, D.L., J.E. Ellis, J.K. Detling, and M.I. Dyer. 1983. Plantherbivore interactions in a North American mixed-grass prairie. II. Responses of bison to modification of vegetation by prairie dogs. Oecologia 56:10-15.

Detling, J.K. 1988. Grasslands and savannas: regulation of energy flow and nutrient cycling by hebivores. p. 131-148: In: L.R. Pomeroy and J.J. Alberts (Eds.) Concepts of ecosystem ecology. A comparative view. Springer-Verlag New York, Inc.

Detling, J.K., and E.L. Palnter. 1983. Defoliation responses of western wheatgrass populations with diverse histories of prairie dog grazing. Oecologia 57:65-71.
Detling, J.K., E.L. Painter, and D.L. Coppock. 1986. Ecotypic differentiation resulting from grazing pressure: evidence for a likely phenomenon. p. 431-433. In: Joss, P.J., P.W. Lynch, and O.B. Williams (eds) Rangelands: a resource under siege. Proc. 2nd Int. Rangeland Congr.. Australian Acad. Sci., Canberra.

Fox, R.L., J.A. Silva, D.L. Plucknett, and D.Y. Teranishi. 1969. Soluble and total silicon in sugar cane. Plant Soil 30:81-82.

Handreck, K.A., and L.H.P. Jones. 1968. Studies of silica in the oat plant. IV. Silica content of plant parts in relation to stage of growth, supply of silica and transpiration. Plant Soil 29:449-459.

Hart, R.H., and E.F. Balla. 1982. Forage production and removal from western and crested wheatgrasses under grazing. J. Range Manage. 35:362-366.

Hilbert, D.W., D.N. Swift, J.K. Detling, and M.I. Dyer. 1981. Relative growth rates and the grazing optimization hypothesis. Oecologia 51:14-18.

Jaramillo, V.J., and J.K. Detling. 1988. Grazing history, defoliation, and competition: effects on shortgrass production and nitrogen accumulation. Ecology 69:1599-1608.

Jones, L.H.P., A.A. Milne, and S.M. Wadham. 1963. Studies of silica in the oat plant. II. Distribution of the silica in the plant. Plant Soil 18:358-371.

Krueger, K. 1986. Feeding relationships among bison, pronghorn and prairie dogs: an experimental analysis. Ecology 67:760-770.

Lanning, F.C., T.L. Hopkins, and J.C. Loera. 1980. Silica and ash content and depositional patterns in issues of mature Zea mays L. plants. Ann. Bot. 45:549-554.

Marschner, H. 1986. Mineral nutrition of higher plants. Academic Press. London.

McNaughton, S.J., and J.L. Tarrants. 1983. Grass leaf silicification: Natural selection for an inducible defense against herbivores. Proc. Nat. Acad. Sci. USA 80:790-791.

McNaughton, S.J., J.L. Tarrants, M.M. McNaughton, and R.H. Davis. 1985. Silica as a defense against herbivory and a growth promotor in African grasses. Ecology 66:528-535.

McNaughton, S.J., and F.S. Chapin. 1985. Effects of phosphorus nutrition and defoliation on $C_{4}$ graminoids from the Serengeti plains. Ecology 66:1617-1629.

Minson, D.J. 1971. The digestibility and voluntary intake of six varieties of Panicum. Aust. J. Exp. Agr. An. Husb. 11:18-25.

Painter, E.L. 1987.Grazing and intraspecific variation in four North American grass species. Ph.D. Diss., Colorado State Univ., Fort Collins.

Painter, E.L., and J.K. Detling. 1981. Effects of defoliation on net photosynthesis and regrowth of western wheatgrass. J. Range Manage. 34:68-71.

Painter, E.L., J.K. Detling, and D.A. Steingraeber. 1989. Grazing history defoliation, and frequency-dependent competition: effects on two North American grasses. Amer. J. Bot. 76:1368-1379.

Polley, H.W., and J.K Detling. 1988. Herbivory tolerance of Agropyron smithii populations with different grazing histories. Oecologia 77:261-267.

Ruess, R.W., S.J. McNaughton, and M.B. Couphenour. 1983. The effects of clipping, nitrogen source and nitrogen concentration on the growth responses and nitrogen uptake of an east African sedge. Oecologia 59:253-261.

Shewmaker, G.E., H.F. Mayland, R.C. Rosenau, and K.H. Asay. 1989. Silicon in C-3 grasses: effect on forage quality and sheep preference. J. Range Manage. 42:122-127.

Stebbins, G.L. 1981. Coevolution of grasses and herbivores. Ann. Missouri Bot. Gard. 68:75-86.

Tanaks, A., and Y.D. Park. 1966. Significance of the absorption and distribution of silica in the growth of the rice plant. Soil Sci. Plant Nutr. 12:23-27.

Truscott, D.R., and P.O. Currie. 1989. Cattle preferences for a hybrid grass; chemical and morphological relationships. J. Range Manage. 42:22-27.

Van Bavel, C.H.M., R. Lascano, and D.R. Wilson. 1978. Water relations of fritted clay. Soil Sci. Soc. Amer. Proc. 42:647-659.

Van Soest, P.J. 1982. Nutritional Ecology of the Ruminant. O\&B Books, Inc., Corvallis, Ore. 